Note on the double star, 99 Herculis.

I desire to call the attention of double star observers to a considerable change in the components of 99 Herculis. The small companion about $10^{1 / 2}$ magnitude, was discovered July 10.1859 by Mr. Alvan Clark at the observatory of Mr. Dawes with a refractor of $81 / 4$ inches aperture. It was measured twice by Dawes as follows:-

$$
\begin{aligned}
& P=347^{\circ} 4 \quad D=1^{\prime \prime} 61 \quad 1859.61 \\
& \begin{array}{lll}
347.0 & 1.80 \quad 1859.65
\end{array}
\end{aligned}
$$

Looking this up recently with the $18^{1 / 2} / 2$-inch refractor of the Dearborn Observatory, there being no record of any other measures than those given above, I failed to see the companion. Later, and under much more favorable conditions, I made the following measures:

$$
\begin{array}{rrr}
P= & 26^{\circ} 6 \\
20.6 & D=1 " 09 & 1878.458 \\
\text { Mean }=\frac{26.1}{24.4} & 0.90 & 1878.460 \\
& \frac{0.97}{0.99} & \frac{1878.473}{1878.46}
\end{array}
$$

It is now a moderately difficult object with the large aperture, except with a very steady air, owing to the great differences in the magnitudes of the stars. It can hardly be doubted that this is a binary system, and it is important that it should be carefully measured. The angular motion for this interval appears to be about $2^{0}$ per annum.

Chicago, June 25, 1878

\title{
Transits of Mercury.
}

The first passage of Mercury across the Sun's disc recorded to have been observed was in the year 1631 . The telescope had begun to come into use twenty years before this. In this interval three transits of Mercury might have been seen in Europe. These occurred on May 3, 1615; November 4, 1618; May 5, 1628: On the occasion of the transit of the planet in 1861 I perceived it easely with a power of 16 on an old ship glass. During the interval referred to there were probably many telescopes in use at least twice as powerful as this one. I have thought it possible that there might be drawings of Sun-spots in existence for these days and that the small black point of Mercury might have been marked on them without the observer being aware what he was recording. The only drawings of Sun spots at this early period that I have seen are those by our countryman Harriot for about the year 1611, those in Galileo's Macchie Solari for 1613: and those in Scheiner's Rosa Ursina for the year 1625. Humboldt in his ,Cosmos' seems to mention some by Jean Tarde.

Among your numerous readers perhaps some interesting information might be drawn forth on this subject.

\begin{tabular}{|c|c|c|c|c|c|c|}
\hline Dates & Heures des obs. & A.R. de $\mathscr{\not}$ & $P$ de $\mathscr{H}$ & Log. & act. par. & $*$ de \\
\hline 1878 & (T.M. $\mathrm{d}$ & & & en A.R. & en $\mathbf{P}$ & Comp. \\
\hline Juillet 25 & $2 \quad 10^{\mathrm{h}} 15^{\mathrm{m}} 22^{\mathrm{s}}$ & $15^{\mathrm{h}} 19^{\mathrm{m}} 5^{0853}$ & $\begin{array}{ll}95^{0} 25^{\prime} 25 & 1 \\
97 & 29\end{array}$ & 1.485 & -0.8141 & $a$ \\
\hline
\end{tabular}

$$
\text { S. J. Johnson, F. R. A. S. }
$$

Upton Helious Rectory Crediton, England.

\section{Observations de la comète périodique de 'Tempel, faites à l'Observatoire de Marseille,} par Mr. Cottenot.

Positions moyennes des étoiles de compariaison pour 1878.0 .

$\begin{array}{lllll}a & 3 \overline{5} 0 \text { Weisse (A.C.) H.XV } & 15^{\mathrm{h} 20^{\mathrm{m}} 41^{\mathrm{B}} 24} & 95^{\circ} 23^{\prime} 20^{\prime \prime} 5 & \text { Cat. W. } \\ b & 413 \mathrm{n} & 15.23 .42 .70 & 97.37 .26 .0 & \end{array}$

In halt:

Zu Nr. 2214. A. Hall. Observations with the 26 inch Refractor of the Naval Observatory. 65. - Elemente und Ephemeride des Cometen von Swift. 71. - L. Schulhof. Éléments corrigés et éphéméride de la comète II 1873 (Tempel). 71. - F. F. Fulius Schmidt. Veränderliche Sterne 1878. 73. - S. W. Burnham. Note on the double star, 99 Herculis. 79. - $S$ F. Fohnson. Transits of Mercury. 79. - Observations de la comète périodique de Tempel, faites à l'Observatoire de Marseille. 79. 